\title{
Atrophic Dermatofibroma: A Comprehensive Literature Review
}

\author{
Philip R. Cohen - Christof P. Erickson · Antoanella Calame
}

Received: May 15, 2019 / Published online: July 23, 2019

(C) The Author(s) 2019 solitary patch with a central umbilicationmost commonly on the shoulder or lower extremity or back—of women aged 48 years or older. Dermoscopy typically showed white scarlike patches; a patchy pigment network was also noted in some lesions. The pathology of an atrophic dermatofibroma has the same features that can be observed in a common fibrous dermatofibroma; there is acanthosis, basal layer hyperpigmentation, and induction of basal cell carcinoma-like features, hair follicle formation or sebaceous hyperplasia in the epidermis and a proliferation of spindle-shaped fibroblasts in the dermis. However, atrophic dermatofibromas also demonstrate depression of the central surface and thinning of the dermis; in many cases, the dermal atrophy is at least $50 \%$. Elastic fibers are either decreased or absent. Similar to nonatrophic dermatofibromas, the immunoperoxidase profile of atrophic dermatofibromas is factor XIIIa-positive and cluster of differentiation 34 (CD34)-negative. The pathogenesis of atrophic dermatofibromas remains to be established.

Conclusion: An atrophic dermatofibroma is an uncommon benign variant of a dermatofibroma. The diagnosis can be suspected based on clinical features and dermatoscopic findings. A biopsy of the lesion will confirm the diagnosis. Periodic evaluation of the lesion site is a reasonable approach to the management of the residual tumor. 
Keywords: Atrophic; Depression; Dermatofibroma; Dermoscopy; Elastic; Fibers; Fibroblast; Men; Umbilication; Women

\section{INTRODUCTION}

An atrophic dermatofibroma-a variant of a dermatofibroma-is an uncommon benign fibrohistiocytic tumor that usually presents in adults as an asymptomatic depressed plaque [1-4]. A comprehensive review of the literature was performed using the PubMed database to search the words: atrophic dermatofibroma; the relevant papers and their references generated by the search were reviewed. The features of this unique neoplasm are presented. Informed consent was obtained from the two participants for inclusion in this study. The patients also signed a consent form providing permission to include relevant clinical photographs in this article.

\section{DISCUSSION}

\section{Dermatofibromas}

Dermatofibromas are benign tumors consisting of fibroblasts and histiocytes [1-4]. They typically occur as solitary lesions; however, multiple dermatofibromas can be associated with various conditions [5]. Several clinical and pathological variants of a dermatofibroma have been described (Table 1) [2-4, 6-11]. An atrophic dermatofibroma is a rare subtype of dermatofibroma [7-30].

\section{History}

Page and Assad are credited with introducing the term 'atrophic dermatofibroma' in 1987 when they described the features of three women with this variant of a dermatofibroma in the Journal of the American Academy of Dermatology [16]. However, in a subsequent paper on this topic, Curco et al. [19] cited another article in the Spanish dermatology literature that was published in 1975 by Gabrielli et al. [15] that reported three women with
Table 1 Variants of a dermatofibroma

Aneurysmal (angiomatoid or vascular)

Angioleiomyoma-associated

Atrophic

Atypical (pseudosarcomatous)

Balloon cell

Cellular

Clear cell

Common fibrous

Cholesterol-associated with hyperlipoproteinemia

Deep penetrating (or subcutaneous)

Eosinophilic intracytoplasmic globule-associated

Epitheloid

Fibrocollagenous

Granular cell-associated

Hemosiderotic

Histiocytic

Keloidal

Lichenoid

Lipidized

Monster cells-associated

Multinodular

Multinucleate cell angiohistiocytoma

Myofibroblast-associated

Myxoid

Osteoclast-like giant cell-associated

Palisading (cutaneous)

Signet ring cell

Smooth muscle-associated

Storiform

dermatofibromas that originally appeared as indurated nodular lesions and spontaneously involuted with subsequent clinical and pathology features of an anetoderma. In addition, in 
Gabrielli et al.'s [15] paper, the authors acknowledge previously published papers in the French literature (from 1960 by Temime and Oddoze [12] and 1964 by Lefranc and Simard [13]) and Spanish literature (from 1968 by Arguelles-Casals and Rodriguez [14]) that described patients with similar lesions.

Significant contributions to the atrophic dermatofibroma literature are summarized in Table 2 [7-9, 11-24]. In this article, we summarize the world literature on this subject. We also present two men with atrophic dermatofibromas in the legends accompanying the figures in this paper (Table 3). They range in age from 45 to 64 years (median age, 55 years). Their fibrohistiocytic lesions are located on their proximal extensor arm (Figs. 1, 2, 3) and upper back (Figs. 4, 5, 6).

\section{Geographic Distribution}

Atrophic dermatofibromas have been observed worldwide; indeed, publications describing individuals with this lesion have originated from Argentina [15], Austria [9], Brazil [26], Canada [16], Cuba [14], France [12, 13], Germany [7], India [28], Italy [23], Japan [17, 18], Korea [20, 25], Mexico [11, 21], Portugal [27], Spain [8, 19], Turkey [22] and the United States $[10,24,29,30]$. Most of the articles (14 of 24, $58 \%$ ) on atrophic dermatofibromas describe one individual $[10,12,13,17-22,24,26,28-30]$; including our paper, two or three patients are reported in six manuscripts (25\%) $[8,15,16,25,27]$. There are only four larger series $(17 \%$ of the publications on atrophic dermatofibromas) which range from 15 to 26 patients $[7,9,11,23]$.

\section{Incidence}

The incidence of atrophic dermatofibromas, as compared to other variants of a dermatofibroma, has been evaluated by five groups of investigators (Table 4) $[9,11,23,27,30]$. Three of the research groups discovered the incidence to be very low, at less than $2 \%[9,27,30]$. Specifically, the incidence ranged from $0.5 \%(1$ of 214 lesions) to $1.7 \%$ (26 of 1526 lesions);
Table 2 Significance of atrophic dermatofibroma publications

\begin{tabular}{|c|c|c|}
\hline $\begin{array}{l}\text { Authors } \\
\text { [reference] }\end{array}$ & $\begin{array}{l}\text { Publication } \\
\text { year }\end{array}$ & Contribution \\
\hline $\begin{array}{l}\text { Temime \& } \\
\text { Oddoze [12] } \\
\text { Lefranc \& } \\
\text { Simard [13] }\end{array}$ & $\begin{array}{l}1960 \\
1964\end{array}$ & $\begin{array}{l}\text { Initial reports from the } \\
\text { French literature of } \\
\text { dermatofibromas that } \\
\text { were umbilicated in the } \\
\text { center and invaginated; } \\
\text { they were referred to as } \\
\text { an invaginated or } \\
\text { refractile histiocytoma } \\
\text { or histiocytofibroma }\end{array}$ \\
\hline $\begin{array}{l}\text { Arguelles- } \\
\text { Casals \& } \\
\text { Rodriguez } \\
{[14]}\end{array}$ & $\begin{array}{l}1968 \\
1975\end{array}$ & $\begin{array}{l}\text { Subsequent reports from } \\
\text { the Spanish literature } \\
\text { that comment on the } \\
\text { existence of an }\end{array}$ \\
\hline $\begin{array}{l}\text { Gabrielle et al. } \\
\text { [15] }\end{array}$ & & $\begin{array}{l}\text { exceptional form of } \\
\text { histiofibroma that is } \\
\text { invaginated or refractile, } \\
\text { and histiocytofibromas } \\
\text { with spontaneous } \\
\text { involution towards } \\
\text { dermal atrophy }\end{array}$ \\
\hline $\begin{array}{l}\text { Page and Asaad } \\
\text { [16] }\end{array}$ & 1987 & $\begin{array}{l}\text { First English literature } \\
\text { publication from } \\
\text { Toronto, Ontario, } \\
\text { Canada, describing an } \\
\text { atrophic' } \\
\text { dermatofibroma in } 3 \\
\text { patients }\end{array}$ \\
\hline Beer et al. [7] & 1991 & $\begin{array}{l}\text { Series of } 15 \text { patients with } \\
\text { atrophic } \\
\text { dermatofibroma from } \\
\text { Munich, Germany }\end{array}$ \\
\hline $\begin{array}{l}\text { Requena \& } \\
\text { Reichel [8] }\end{array}$ & 1995 & $\begin{array}{l}\text { Report of } 2 \text { patients from } \\
\text { Madrid, Spain, and } \\
\text { proposing the name } \\
\text { 'delled' dermatofibroma }\end{array}$ \\
\hline Zelger et al. [9] & 1995 & $\begin{array}{l}\text { Largest series of } 26 \\
\text { patients from } \\
\text { Innsbrook, Austria }\end{array}$ \\
\hline
\end{tabular}


Table 2 continued

\begin{tabular}{|c|c|c|}
\hline $\begin{array}{l}\text { Authors } \\
\text { [reference] }\end{array}$ & $\begin{array}{l}\text { Publication } \\
\text { year }\end{array}$ & Contribution \\
\hline $\begin{array}{l}\text { Kiyohara } \\
\text { et al. [17] }\end{array}$ & 2000 & $\begin{array}{l}\text { Demonstrated loss of elastic } \\
\text { fibers and } \\
\text { elastophagocytosis by the } \\
\text { atrophic dermatofibroma } \\
\text { cells }\end{array}$ \\
\hline $\begin{array}{l}\text { Ohnishi et al. } \\
\text { [18] }\end{array}$ & 2004 & $\begin{array}{l}\text { Confirm loss of elastic } \\
\text { fibers in an atrophic } \\
\text { dermatofibroma }\end{array}$ \\
\hline $\begin{array}{l}\text { Curco et al. } \\
{[19]}\end{array}$ & $\begin{array}{l}2006 \\
2009\end{array}$ & $\begin{array}{l}\text { Three patients with a } \\
\text { combined }\end{array}$ \\
\hline $\begin{array}{l}\text { Shin et al. } \\
{[20]}\end{array}$ & 2016 & $\begin{array}{l}\text { dermatofibroma in which } \\
\text { there is coexistence of }\end{array}$ \\
\hline $\begin{array}{l}\text { Villarreal- } \\
\text { Martinez } \\
\text { et al. [21] }\end{array}$ & & $\begin{array}{l}\text { two variant patterns in a } \\
\text { single lesion: aneurysmal } \\
\text { and atrophic } \\
\text { dermatofibroma }\end{array}$ \\
\hline $\begin{array}{l}\text { Kilinic } \\
\text { Karaarslan } \\
\text { et al. } \\
\text { [22] }\end{array}$ & 2007 & $\begin{array}{l}\text { First report of the } \\
\text { dermoscopic features of } \\
\text { an atrophic } \\
\text { dermatofibroma }\end{array}$ \\
\hline $\begin{array}{l}\text { Ferrari et al. } \\
\qquad[23]\end{array}$ & $\begin{array}{l}2013 \\
2017\end{array}$ & $\begin{array}{l}\text { Confirm 'multiple white } \\
\text { scar-like patches' and }\end{array}$ \\
\hline $\begin{array}{l}\text { Kelati et al. } \\
{[11]}\end{array}$ & & $\begin{array}{l}\text { 'patchy pigment network' } \\
\text { pattern on dermoscopic } \\
\text { examination of an } \\
\text { atrophic dermatofibroma }\end{array}$ \\
\hline $\begin{array}{l}\text { Reynolds } \\
\text { et al. [24] }\end{array}$ & 2014 & $\begin{array}{l}\text { A patient with a combined } \\
\text { dermatofibroma: } \\
\text { agminated (multiple } \\
\text { clustered) and focally } \\
\text { atrophic }\end{array}$ \\
\hline
\end{tabular}

Table 2 continued

\begin{tabular}{|c|c|c|}
\hline $\begin{array}{l}\text { Authors } \\
\text { [reference] }\end{array}$ & $\begin{array}{l}\text { Publication } \\
\text { year }\end{array}$ & Contribution \\
\hline $\begin{array}{l}\text { Cohen } \\
\text { et al. } \\
{[\mathrm{CR}]}\end{array}$ & 2019 & $\begin{array}{l}\text { Two men with an atrophic } \\
\text { dermatofibroma on the } \\
\text { upper extremity (one } \\
\text { patient), and the upper back } \\
\text { (one patient) are presented, } \\
\text { and a comprehensive review } \\
\text { of this benign } \\
\text { fibrohistiocytic lesion is } \\
\text { provided }\end{array}$ \\
\hline
\end{tabular}

$C R$ current report, $P u b$ publication

combining the 3 studies showed the incidence to be $1.5 \%$ (29 of 1932 lesions).

However, more recently, two studies demonstrated a much higher incidence ranging from 14 to $18 \%$; however, in these investigations, a pathology confirmation of the diagnosis was not confirmed [11, 23]. If the definitive diagnosis of an atrophic dermatofibroma was based upon the pathologic criteria of more than a $50 \%$ reduction of dermal thickening beneath the lesion [9], it is possible that the higher incidence of atrophic dermatofibromas that the later investigators noted may have been overestimated since some of their diagnoses were only determined by the clinical appearance of the lesion $[11,23]$. Indeed, when one of the groups of earlier investigators were screening 1526 dermatofibroma pathology specimens, they observed a minimum of $16.4 \%$ (more than 250) dermatofibromas with dermal atrophy of less than $50 \%$ of the surrounding dermis and did not include the lesions in their study of 26 atrophic dermatofibromas which resulted in the significantly lower incidence that they recorded of $1.7 \%$ [9]. 
Table 3 Clinical and pathologic features of two men with an atrophic dermatofibroma

\begin{tabular}{|c|c|c|}
\hline Feature & Patient 1 & Patient 2 \\
\hline Diagnosis age & 45 years & 64 years \\
\hline Duration of lesion & More than 3 years & 1 year \\
\hline Race & Caucasian & Caucasian \\
\hline Location & Left shoulder & Left upper back \\
\hline $\begin{array}{l}\text { History of trauma to } \\
\text { site }\end{array}$ & None & None \\
\hline $\begin{array}{l}\text { History of injection } \\
\text { at site }\end{array}$ & None & None \\
\hline $\begin{array}{l}\text { Past medical skin } \\
\text { history }\end{array}$ & Cystic acne as a youth & None \\
\hline Symptoms & None & None; wife noticed lesion \\
\hline Color & Flesh & Flesh \\
\hline Morphology & $\begin{array}{l}15 \times 15-\mathrm{mm} \text { area of induration surrounding a } \\
10 \times 10-\mathrm{mm} \text { depressed area with } \\
\text { telangiectasias; positive dimple sign }\end{array}$ & $6 \times 6-\mathrm{mm}$ depressed area \\
\hline $\begin{array}{r}\text { Differential } \\
\text { diagnosis }\end{array}$ & Dermatofibroma (atrophic) & Dermatofibroma (atrophic) \\
\hline $\begin{array}{l}\text { Epithelial } \\
\text { hyperplasia }\end{array}$ & Acanthosis & Seborrheic keratosis-like \\
\hline $\begin{array}{l}\text { Basal layer } \\
\text { hyperpigmentation }\end{array}$ & Present & Present \\
\hline $\begin{array}{l}\text { Sebaceous gland } \\
\text { formation }\end{array}$ & None & None \\
\hline $\begin{array}{l}\text { Hair follicle } \\
\text { formation }\end{array}$ & None & None \\
\hline $\begin{array}{l}\text { Basal cell carcinoma- } \\
\text { like }\end{array}$ & None & None \\
\hline Dermal atrophy & Present & Present \\
\hline $\begin{array}{l}\text { Verhoff-Van Gieson } \\
\text { stain }\end{array}$ & $\begin{array}{l}\text { Absence of elastic fibers in the tumor; however, } \\
\text { elastic fibers present beneath the } \\
\text { dermatofibroma }\end{array}$ & $\begin{array}{l}\text { Absence of elastic fibers in more than } 90 \% \text { of the } \\
\text { dermatofibroma; elastic fibers present in the } \\
\text { superficial portion of the tumor in the papillary } \\
\text { dermis and beneath the tumor }\end{array}$ \\
\hline
\end{tabular}

$m m$ millimeters 


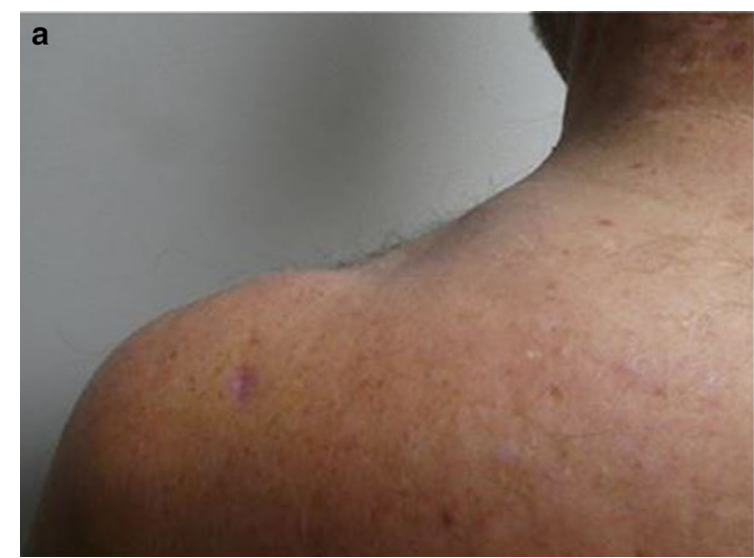

Fig. 1 Atrophic dermatofibroma: left shoulder of a 45-year-old Caucasian man. Distant (a) and closer (b) views of an asymptomatic lesion on the left shoulder of more than 3 years of duration. There was no prior history of trauma or injection to the site. As a youth, he had cystic acne. The lesion appeared as a $15 \times 15-\mathrm{mm}$ flesh-colored indurated patch surrounding a $10 \times 10-\mathrm{mm}$

\section{Epidemiology}

Atrophic dermatofibromas have been described-including the two individuals in this report-in 102 patients [7-30]. Several of the reports did not provide the patient's gender or other clinical features [11-14, 22, 23, 27]. However, demographic information was provided for 64 individuals with atrophic dermatofibroma (Tables 5 and 6) [7-30].

Atrophic dermatofibromas occur more often in women $(53 / 64,83 \%)$ than men $(11 / 64,17 \%)$. The ratio of women to men is nearly $5: 1$. Similarly, a female prevalence has also been observed in individuals with other types of dermatofibromas, ranging from 2.2:1 [31] to 2.6:1 [3] to 5:1 [9].

The age-when the diagnosis of atrophic dermatofibroma was established-ranged from 12 to 86 years (median, 45 years). The women ranged in age from 12 to 86 years (median, 48 years). The men ranged in age from 27 to 78 years (median, 40 years).

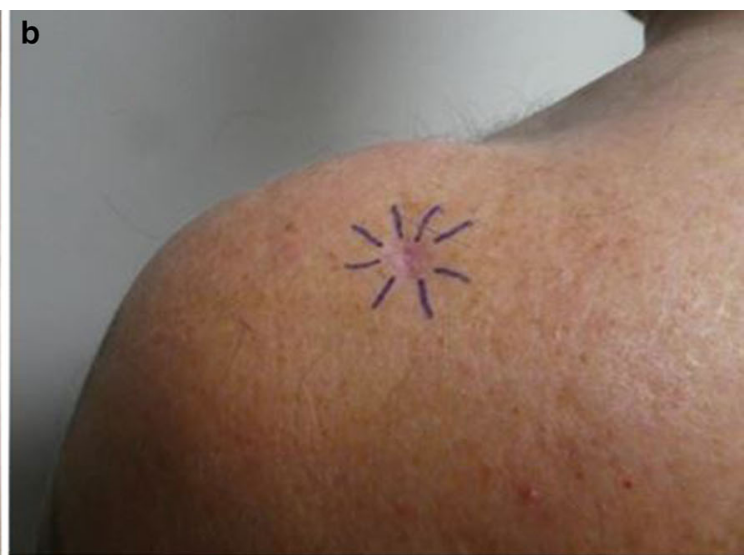

telangiectatic depressed central area; the lesion is outlined by the purple lines $(\mathbf{b})$. Squeezing the edges of the lesion between the examiner's thumb and index finger produced a dimpling of the central portion of the lesion. The submitted clinical differential diagnosis was an atrophic dermatofibroma

\section{Duration}

The duration of time that the atrophic dermatofibroma was noted prior to establishing the diagnosis was described in 11 women (Table 5) [7-18, 21-23, 25-29] and 5 men (Table 6) $[7-9,11-14,19,20,22-24,27,30]$; also, the average duration of the lesion was 5.8 years in an additional 11 patients [7]. Therefore, the dermatofibroma was present from 3 to more than 40 years (median, 8 years) in the women and from 1 to 20 years (median, 3 years) in the men before the diagnosis was confirmed. Overall, for the 31 patients in whom this information was provided, the tumor was initially observed between 1 to more than 40 years (median, 6 years) prior to diagnosis.

\section{Symptoms}

Atrophic dermatofibromas are usually asymptomatic. However, some of the patients noted their lesion to either be painful (Table 6, cases 1 and 5) or increasing in size caused by either progressive enlargement or swelling (Table 5, case 32 and Table 6, case 1, respectively). None 

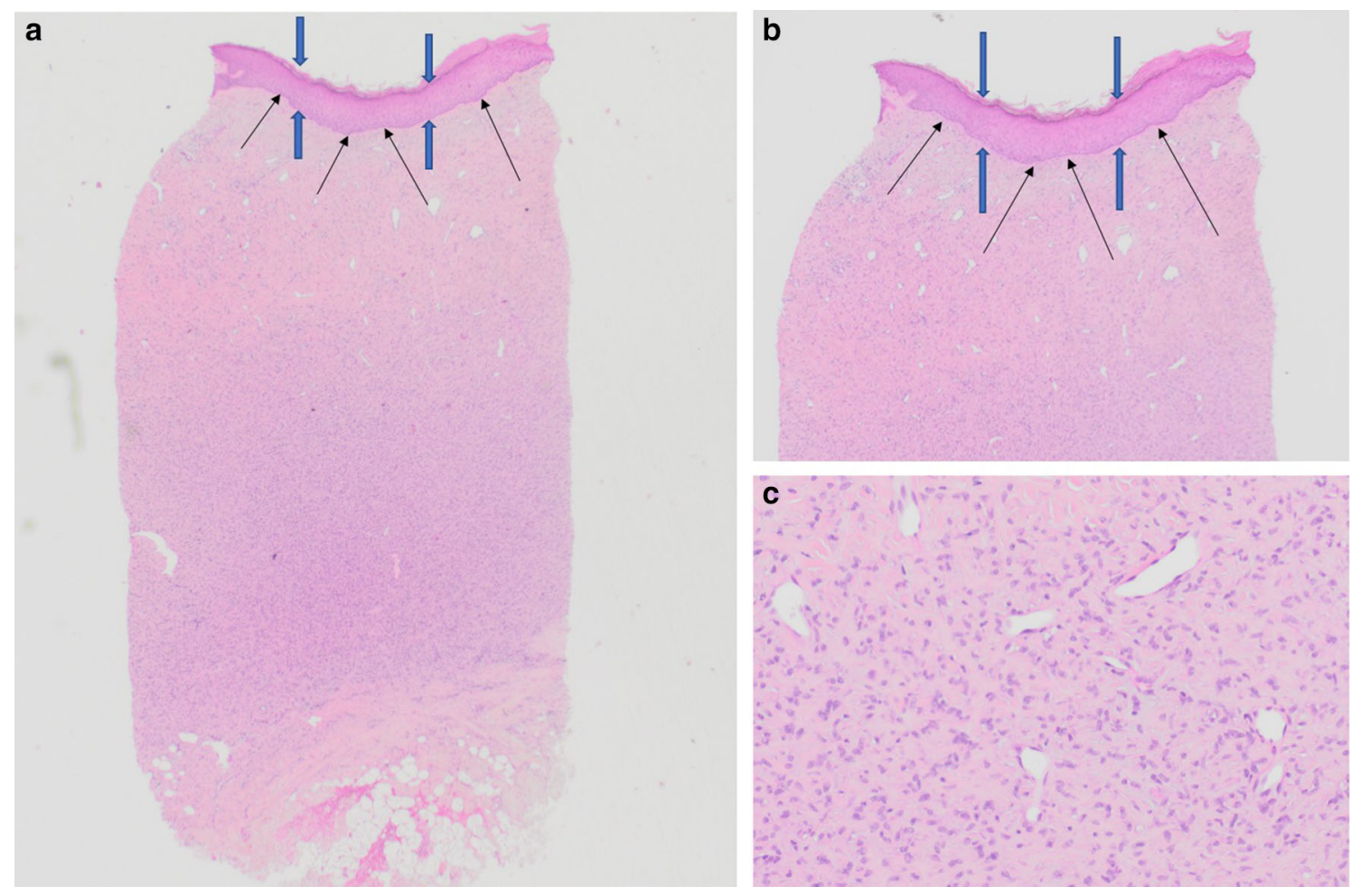

Fig. 2 Atrophic dermatofibroma on the left shoulder of a 45-year-old Caucasian man: pathology features of hematoxylin and eosin-stained sections. Low magnification (a) and higher magnification (b, c) views of a $3-\mathrm{mm}$ punch biopsy from the central portion of the depressed area show epidermal acanthosis (between blue arrows) with

of the patients had a history of trauma or insect bite or steroid injection to the location.

\section{Clinical Presentation}

Atrophic dermatofibromas typically presented as a solitary patch with a central umbilication. However, some of the pathology-confirmed atrophic dermatofibromas presented as nodular lesions [7, 11]. In addition, at least 4 women (Table 5, cases $7,19,23$, and 31) $[15,26]$ and one man (Table 6, case 3) [24] had multiple tumors. The 33-year-old man's lesions presented as an agminated cluster of tumors, which occasionally itched, on his left thigh [24].

The size of the tumor varied from $5 \times 7 \mathrm{~mm}$ [10] to $5 \times 5 \mathrm{~cm}$ [19]. The texture of the patch was either indurated or soft or similar to that of the surrounding skin. Its appearance also basal layer hyperpigmentation (black arrows) $(\mathbf{a}, \mathbf{b})$. There is atrophy of the dermis, and the dermal tumor shows an increased number of fibroblasts with trapped collagen bundles in the periphery (hematoxylin and eosin: $\mathbf{a} \times 2$; b $\times 4$; $\mathbf{c} \times 20$ )

varied; the patch was either flesh-colored, brown or erythematous.

\section{Location}

The location of the atrophic dermatofibromas, in 64 patients in whom the site was provided, are summarized in Table 7 [7-30]. Most of the lesions $(46,72 \%)$ were found above the waist. Only $28 \%$ (18) of the tumors were located on legs or buttocks.

The most common locations of atrophic dermatofibromas were the shoulder (16 patients, 25\%; Fig. 1), the lower extremity (15 patients, 23.4\%) and the back (11 patients, 17.2\%; Fig. 4). The lesions were also observed on the arm (six patients, 9.4\%), the trunk (five patients, $7.8 \%$ ) and the breast (four patients, $6.2 \%$ ). The axilla (three patients, $4.7 \%$ ), the 

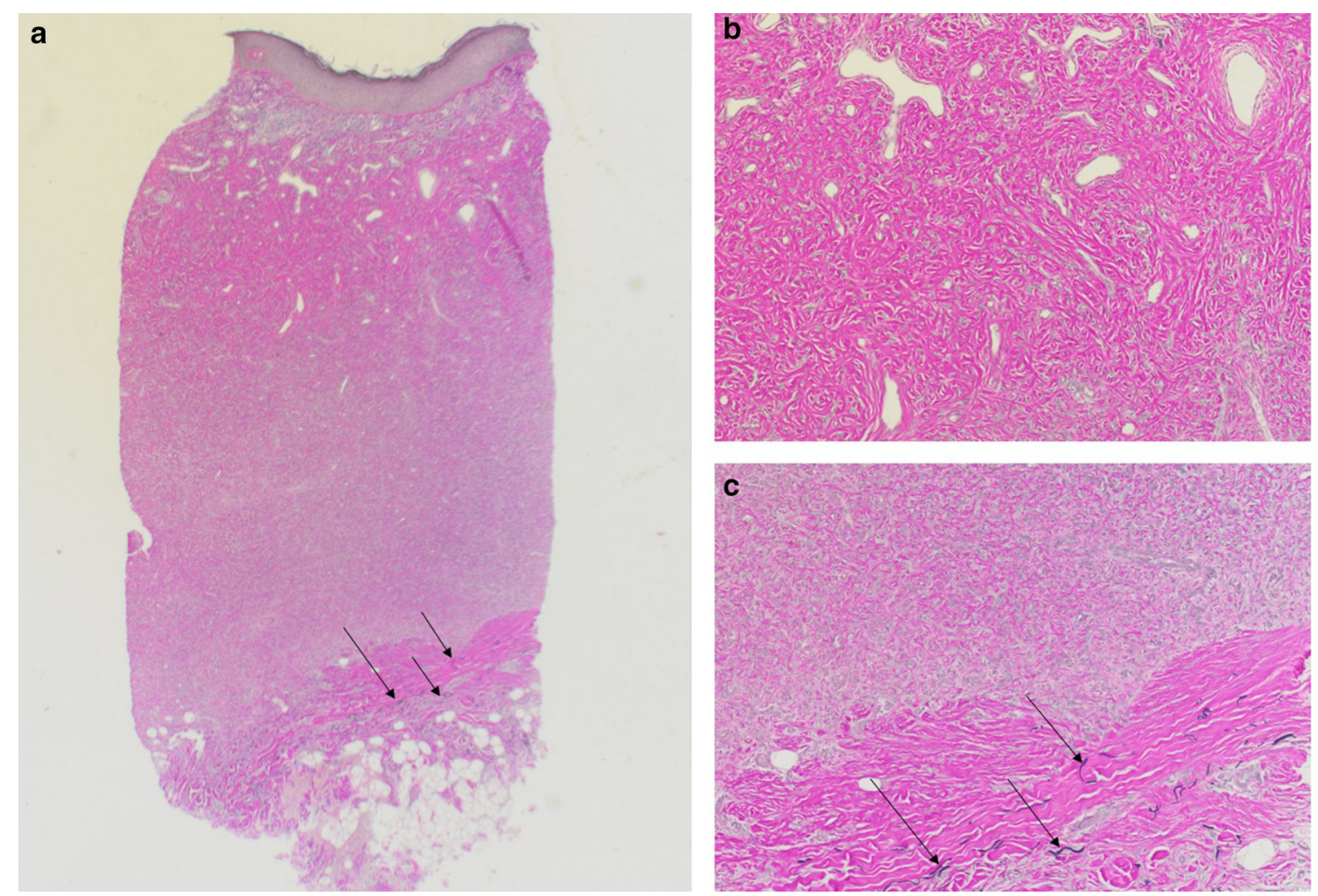

Fig. 3 Atrophic dermatofibroma on the left shoulder of a 45-year-old Caucasian man: pathology features of Verhoeff-Van Gieson-stained sections. Low magnification (a) and higher magnification (b, c) views of a $3-\mathrm{mm}$ punch biopsy from the central portion of the depressed

buttock (three patients, $4.7 \%$ ) and the neck (one patient, 1.6\%) were less frequent sites.

The atrophic dermatofibroma site varied in the 40 women and 9 men for which the location was given. Similar to women with non-atrophic dermatofibromas, the lower extremity was the most common location $(10,25 \%)$; other frequent sites included the shoulder $(9,22.5 \%)$ and the back $(7,17.5 \%)$. However, in the men, the back $(4,44.5 \%)$ and the thigh $(2,22.2 \%)$ were the predominant locations.

\section{Dermoscopy}

Dermatoscopic features most often observed in common fibrous dermatofibromas include a central white patch and a pigment network $[12,23,31]$. However, the features of atrophic area show an absence of elastic fibers in the tumor. However, elastic fibers (which stain black and are demonstrated by black arrows) can be noted in the deep dermis beneath the dermatofibroma (a, c) (Verhoeff-Van Gieson: $\mathbf{a} \times 2 ; \mathbf{b} \times 20 ; \mathbf{c} \times 20$ )

dermatofibromas-included in the studies of multiple dermatofibromas-were described by three groups of investigators [11, 22, 23]. All observed the same patterns.

A single individual with an atrophic dermatofibroma was included in a study of 52 dermatofibromas from 37 patients. The morphologic presentation was a $1.2 \times 1.0-\mathrm{cm}$ atrophic plaque; the suspected clinical diagnosis was a morpheaform basal cell carcinoma. Multiple small scar-like areas and a patchy distribution pigment network (that was prominent at the periphery) were observed with dermoscopy; therefore, the diagnosis of a melanocytic neoplasm was entertained dermoscopically. However, pathology revealed an atrophic dermatofibroma [22].

Both of the latter groups of investigators confirmed the previously described 


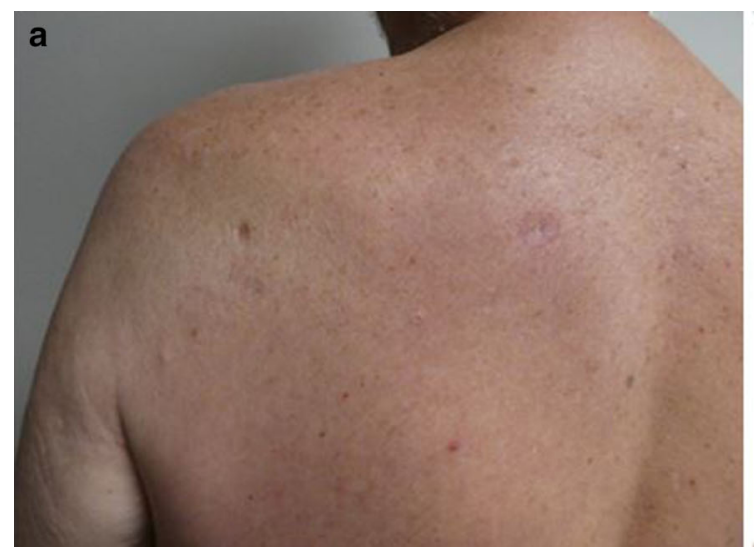

Fig. 4 Atrophic dermatofibroma: left upper back of a 64-year-old Caucasian man. Distant (a) and closer (b) views of an asymptomatic lesion on the left upper back of 1-year duration that had been noticed by his wife. There was no prior history of trauma or injection to the

dermoscopic observations. Specifically, in 10 of 16 atrophic dermatofibromas (from a group of 130 dermatofibromas in 115 patients), a dermatoscopic pattern of multiple white scar-like patches was noted; the researchers also commented that this pattern of multiple white scarlike patches could be observed in dermatofibromas with sebaceous hyperplasia [23]. The other researcher's evaluation of 100 dermatofibromas from 95 patients revealed that 17 atrophic dermatofibromas not only had a dermoscopic pattern of patchy pigment network but also a pattern of white patches [11].

A 40-year-old woman with a combined (aneurysmal and atrophic) dermatofibroma [6] on her upper arm was described. Her $1.5-\mathrm{cm}$ tumor presented as a non-tender erythematous atrophic plaque. In addition to a pigment network and scar-like white patches, dermoscopy revealed arborizing vessels arising from a bluish homogenous area resembling a flame pattern [21].

Dermoscopic features of an atrophic dermatofibroma on the right mid-back of a 64-year-old man were also reported. The $12 \times 8$-mm indented red plaque showed a poorly defined erythematous lesion with a stellate white scar-like area and white-to-yellow lobules. The latter pattern of lobules

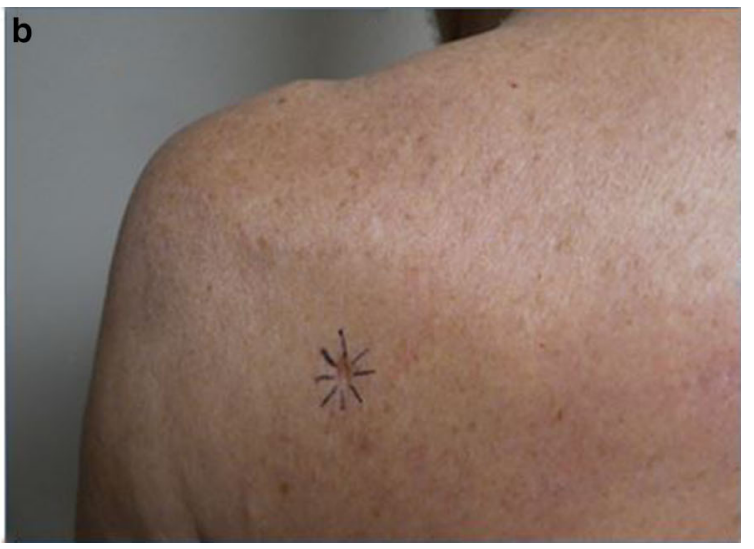

site. The lesion appeared as a $6 \times 6-\mathrm{mm}$ flesh-colored depressed area; the lesion is outlined by the purple lines (b). The submitted clinical differential diagnosis was an atrophic dermatofibroma

corresponded to sebaceous hyperplasia induced by the dermatofibroma [30].

\section{Pathology}

\section{Hematoxylin and Eosin Staining}

The histopathology of common fibrous dermatofibroma is characterized by a proliferation of spindle-shaped fibroblasts in the dermis; histiocytes, collagen and blood vessels are also present. The fibrous cells often are arranged in a storiform, whirling pattern. A zone of normally appearing collagen in the papillary dermis (Grenz zone) is often present between the overlying epidermis and the dermal lesion [1-4].

The epidermis is frequently acanthotic. Indeed, it may mimic the appearance of a seborrheic keratosis. In addition, hyperpigmentation of the epidermal basal layer, induction of basal cell carcinoma-like features, hair follicle formation or sebaceous hyperplasia may be present [1-4].

In addition to the common fibrous dermatofibroma, there are several other variants of a dermatofibroma (Table 1) [2-4, 6-11]. Each of these has its own unique and distinctive pathologic features. Although the clinical presentation of an atrophic dermatofibroma can 

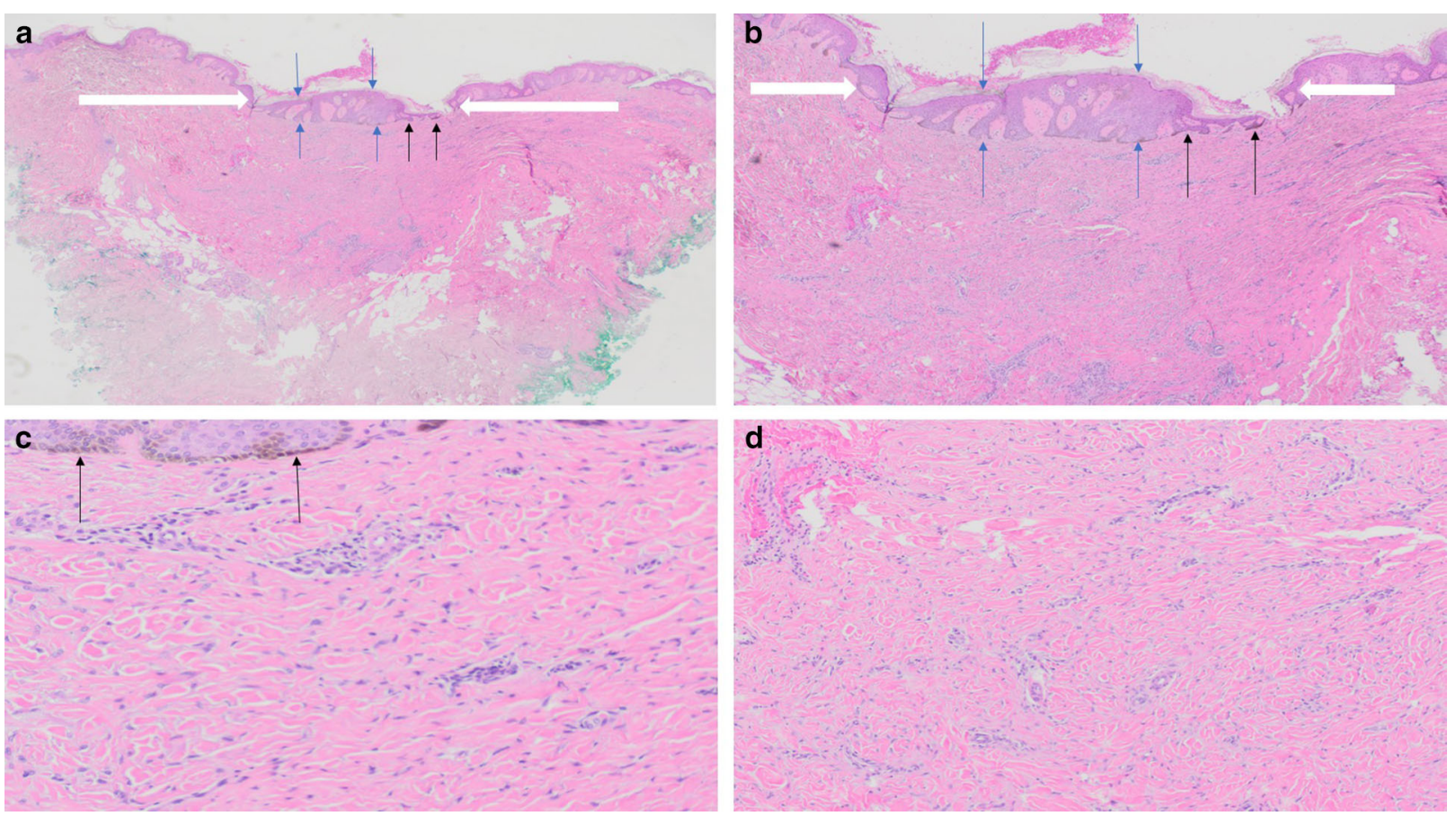

Fig. 5 Atrophic dermatofibroma on the left upper back of a 64-year-old Caucasian man: pathology features of hematoxylin and eosin-stained sections. Low magnification (a) and higher magnification (b-d) views of an $8-\mathrm{mm}$ punch biopsy show a depressed area in the central portion of the specimen (between white arrows). The epidermis has seborrheic keratosis-like hyperplasia (between blue

often be differentiated from that of a common fibrous dermatofibroma, the pathologic changes observed in the atrophic variant shares several similarities with those noted in a common fibrous dermatofibromas.

Page and Assaad's initial description of 'atrophic dermatofibroma' in 1987 was based the clinical presentation of the tumors-either an atrophic plaque or a pit-like depression or a depressed patch. Two of the three lesions demonstrated extreme cellularity which the investigators postulated explained the typical sinking in of the biopsy punch into the lesion. However, the third atrophic dermatofibroma, on the breast of a 46-year-old woman, showed pathologic changes of a typical fibrous dermatofibroma [16].

The next study, by Beer et al. in 1991, of 15 atrophic dermatofibromas revealed similar features in all of the tumors: at low magnification,

arrows) (a, b) and hyperpigmentation of the basal layer (black arrows) $(\mathbf{a}-\mathbf{c})$. The center depression reveals atrophy of the dermis (a, b). The dermal tumor consists an increased number of fibroblasts with trapped collagen bundles in the periphery (a-d) (Hematoxylin and eosin: $\mathbf{a} \times 2 ; \mathbf{b} \times 4 ; \mathbf{c} \times 20 ; \mathbf{d} \times 10$ )

there was acanthosis and papillomatosis of the epidermis, depression of the central surface and thinning of the dermis; however, the extent of dermal thinning was not quantified. Epidermal changes similar to those noted in common fibrous dermatofibromas-follicular differentiation (five cases), sebaceous differentiation (four cases) and basal cell carcinoma-like changes (three cases)-were also present. All of the tumors penetrated into the subcutaneous fat. The investigators arbitrarily defined two atrophic dermatofibroma histologic subtypes: moderately atrophic type (which had only moderate thinning of the dermis) and pronounced atrophic type (which had pronounced thinning of the reticular dermis, collagen bundle homogenization and decreased cellularity) [7].

In contrast to these earlier researchers, Requena and Reichel did not observe any 

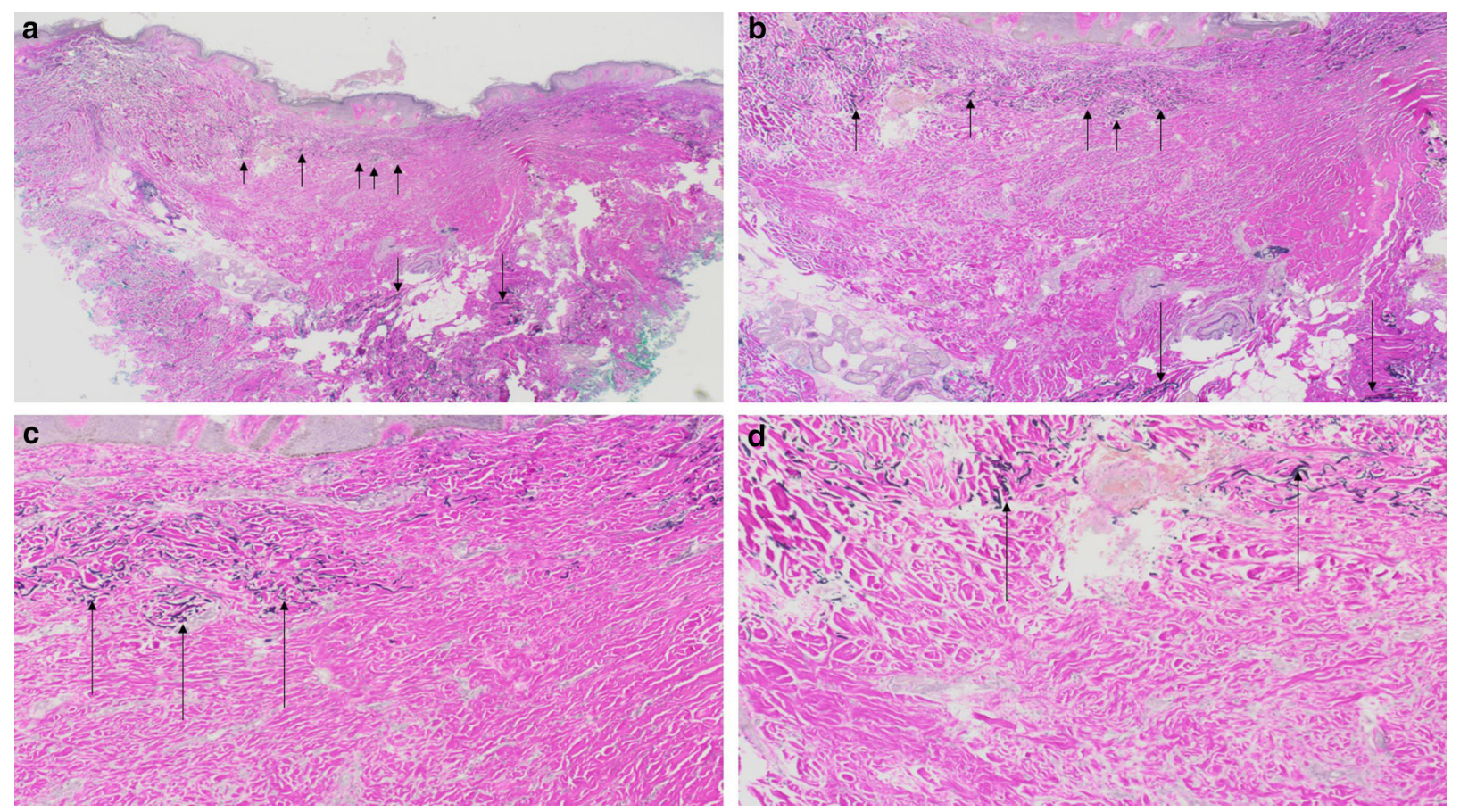

Fig. 6 Atrophic dermatofibroma on the left upper back of a 64-year-old Caucasian man: pathology features of Verhoeff-Van Gieson-stained sections. Low magnification (a) and higher magnification (b-d) views of an $8-\mathrm{mm}$ punch biopsy show an absence of elastic fibers in more than $90 \%$ of the dermatofibroma. Elastic fibers (which

stain black and are demonstrated by black arrows) are only present in the superficial portion of the tumor in the papillary dermis $(\mathbf{a}-\mathbf{d})$. In addition, black staining of elastic fibers (black arrows) can be observed in the deep dermis beneath the dermatofibroma (a, b) (Verhoeff-Van Gieson: $\mathbf{a} \times 2 ; \mathbf{b} \times 4 ; \mathbf{c} \times 10 ; \mathbf{d} \times 20)$

Table 4 Incidence of atrophic dermatofibromas

\begin{tabular}{lccc}
\hline $\begin{array}{l}\text { Number of patients with an } \\
\text { atrophic dermatofibroma }\end{array}$ & $\begin{array}{l}\text { Number of patients evaluated with } \\
\text { a dermatofibroma }\end{array}$ & $\begin{array}{l}\text { Incidence of an atrophic } \\
\text { dermatofibroma (\%) }\end{array}$ & Reference \\
\hline 1 & 214 & 0.5 & {$[21]$} \\
2 & 192 & 1.0 & {$[16]$} \\
26 & 1526 & 1.7 & {$[5]$} \\
16 & 115 & 13.9 & {$[14]$} \\
17 & 95 & 17.9 & {$[20]$} \\
\hline
\end{tabular}

dermal atrophy in their microscopic evaluation of the atrophic dermatofibromas from two women. Instead, they only observed a central dell; there was no thinning or loss of preexisting collagen bundles in the dermis. Hence, they attributed the clinical appearance of atrophy to be the result of a central depression instead of authentic atrophy [8].

However, in 1995, Zelger et al. suggested that the predominant histopathologic feature of an atrophic dermatofibroma should be dermal atrophy of more than $50 \%$ of the locoregional 
Table 5 Clinical characteristics of 53 women with an atrophic dermatofibroma

\begin{tabular}{|c|c|c|c|c|c|}
\hline C & DxA & Dur & Location & Differential diagnosis & Ref. \\
\hline 1 & $12 y$ & NS & Upper arm & Bowen's disease, dermatofibroma & $9 \mathrm{C} 3$ \\
\hline 2 & $19 \mathrm{y}$ & NS & Neck & NS & $25 \mathrm{C} 2$ \\
\hline 3 & $22 y$ & NS & Breast & Dermatofibroma & $9 \mathrm{C} 21$ \\
\hline 4 & $28 \mathrm{y}$ & NS & Shoulder & Umbilicated tumor cutis & $9 \mathrm{C} 10$ \\
\hline 5 & $30 y$ & NS & Axilla & Dermatofibroma & $9 \mathrm{C} 26$ \\
\hline 6 & $30 y$ & $3 y$ & Left lower leg & Panniculitis & $28 \mathrm{C} 1$ \\
\hline 7 & $36 y$ & $17 y$ & Right leg & NS & $15 \mathrm{C} 2$ \\
\hline 8 & $37 y$ & NS & Lower leg & Pigmented dermatofibroma & $9 \mathrm{C} 11$ \\
\hline 9 & $39 y$ & NS & Buttock & Basal cell carcinoma & $9 \mathrm{C} 4$ \\
\hline 10 & $40 y$ & $10 y$ & Left upper arm & NS & 21 \\
\hline 11 & $41 y$ & NS & Mid back & Atrophic scar, basal cell carcinoma & $16 \mathrm{C} 5$ \\
\hline 12 & $41 y$ & NS & Right shin & NS & $25 \mathrm{C} 1$ \\
\hline 13 & $42 y$ & NS & Shoulder & Dermatofibroma, scar & $9 \mathrm{C} 14$ \\
\hline 14 & $42 y$ & $8 y$ & Upper back & NS & $15 \mathrm{C} 3$ \\
\hline 15 & $43 y$ & NS & Thigh & Dermatofibroma & $9 \mathrm{C} 9$ \\
\hline 16 & $43 y$ & NS & Shoulder & Tumor cutis & $9 \mathrm{C} 13$ \\
\hline 17 & $44 y$ & NS & Shoulder & Basal cell carcinoma, dermatofibroma & $9 \mathrm{C} 18$ \\
\hline 18 & $45 y$ & NS & Shoulder & Nevus & $9 \mathrm{C} 20$ \\
\hline 19 & $45 y$ & NS & Right axilla & Anetoderma & 10 \\
\hline 20 & $46 y$ & NS & Breast & Anetoderma & $16 \mathrm{C} 3$ \\
\hline 21 & $50 y$ & NS & Breast & Sarcoidosis & $9 \mathrm{C} 1$ \\
\hline 22 & $50 y$ & NS & Shoulder & Scar & $9 \mathrm{C} 2$ \\
\hline 23 & $50 \mathrm{y}$ & $6 y$ & Thigh & NS & $15 \mathrm{C} 1$ \\
\hline 24 & $51 y$ & NS & Lower leg & Dermatofibroma & $9 \mathrm{C} 8$ \\
\hline 25 & $55 y$ & NS & Buttock & Tumor cutis & $9 \mathrm{C} 16$ \\
\hline 26 & $55 y$ & NS & Shoulder & Nevus & $9 \mathrm{C} 23$ \\
\hline 27 & $55 y$ & $6.5 \mathrm{y}$ & Left upper back & NS & 17 \\
\hline 28 & $56 y$ & NS & Shoulder & NS & $9 \mathrm{C} 6$ \\
\hline 29 & $56 y$ & NS & Back & Umbilicated skin lesion & $9 \mathrm{C} 17$ \\
\hline 30 & $56 y$ & $3 y$ & Right thigh & NS & $8 \mathrm{C} 2$ \\
\hline 31 & $57 y$ & $10 y$ & Left flank & NS & 26 \\
\hline 32 & $63 y$ & $5 y$ & Left arm & NS & $8 \mathrm{C} 1$ \\
\hline 33 & $64 y$ & NS & Back & Basal cell carcinoma, scar & $9 \mathrm{C} 5$ \\
\hline
\end{tabular}


Table 5 continued

\begin{tabular}{llllll}
\hline C & DxA & Dur & Location & Differential diagnosis & Ref. \\
\hline 34 & $64 y$ & $>40 y$ & Left thigh & Anetoderma, atrophoderma, basal cell carcinoma, morphea, scar & 29 \\
35 & $66 y$ & NS & Shoulder & Tumor cutis & 9 C22 \\
36 & $66 y$ & NS & Axilla & Neurofibroma & 9 C25 \\
37 & $69 y$ & $16 y$ & Left thigh & Dermatofibroma, scar & 18 \\
38 & $73 y$ & NS & Breast & Scar & 9 C24 \\
39 & $76 y$ & NS & Back & Nevus & 9 C13 \\
40 & $86 y$ & NS & Upper back & Dermatofibroma, DFSP & 16C4 \\
$41-53^{\text {a }}$ & FN & FN & FN & FN & 7 \\
\hline
\end{tabular}

38 additional patients with an atrophic dermatofibroma have been described; however, neither the gender nor other clinical features were described [11-14, 22, 23, 27]

$C$ case, DFSP dermatofibrosarcoma protuberans, $D x A$ diagnosis age, $D u r$ duration of lesion prior to diagnosis, $F N$ footnote, $L$ left, $N S$ not stated, $R$ right, $R e f$ reference, $y$ year

a A retrospective pathology-originating study identified 15 patients ( 2 men and 13 women) ranging from 19 to 79 years (median $=49.5$ years) with an atrophic dermatofibroma who were observed in 2 years; the tumors had been present for an average duration of 5.8 years. The tumors were located on the shoulder (6), upper arm (3), lower limbs (3) and trunk (3). There was no identifiable cause and no previous steroid injections. The tumors presented as flat or retracted lesions (7) or nodules (4). The clinical differential diagnoses (23 submitted for the 15 patients) included basal cell carcinoma (10), scar (6), atrophy (1), Bowen's disease (1), dermatofibromasarcoma protuberans (1), lupus erythematosus (1), necrobiosis lipoidica (1), nevus lipomatosus (1) and nonspecific granuloma (1) [7]

dermis. They described the features of 25 patients with an atrophic dermatofibroma. They also commented that during the screening of lesions to include in their study, they encountered more than 250 dermatofibromas with dermal atrophy of less than 50\% [9].

A combined dermatofibroma is a dermatofibroma that demonstrates the coexistence of two variant patterns in a single lesion [6]. Three patients (two men $[19,20]$ and one woman $[21]$ ) had combined (atrophic and aneurysmal) dermatofibromas. The tumors were on the back [20], upper trunk [19] and upper arm [21]. The woman's lesion was asymptomatic [21]; however, both of the men's tumor was painful $[19,20]$.

Our patients had epithelial hyperplasia (either acanthosis or seborrheic keratosis-like proliferation of the epidermis), basal layer hyperpigmentation of the epidermis, and a depression in the center portion of the specimen (Figs. 2 and 5). In addition, both men had dermal atrophy (Table 3); this is more readily observed in the lesion from the left upper back of the 64-year-old man (Fig. 5). The dermal tumor shows an increased number of fibroblasts with trapped collagen bundles in the periphery.

\section{Elastic Fiber Staining}

Several investigators have noticed that elastic fibers are either decreased or absent in atrophic dermatofibromas [17, 18, 26, 30]. In contrast, Curco et al. observed normal elastic fibers in the combined dermatofibroma (with features of both an atrophic and aneurysmatic dermatofibroma) of 10-years duration on the left upper trunk of a 40-year-old man [19]. However, in non-atrophic dermatofibromas, some of the researchers also observed decreased elastic fibers $[6,8]$, whereas other investigators noted that 
Table 6 Clinical characteristics of 11 men with an atrophic dermatofibroma

\begin{tabular}{llllll}
\hline C & DxA & Dur & Location & Differential diagnosis & Ref. \\
\hline 1 & $27 y$ & $2 y$ & Back & Inflamed seborrheic keratosis, melanoma & 20 \\
2 & $32 y$ & NS & Thigh & Nevus & 9 C19 \\
3 & $33 y$ & $20 y$ & L thigh & NS & 24 \\
4 & $40 y$ & NS & Buttock & Dermatofibroma & 9 C7 \\
5 & $40 y$ & $10 y$ & L upper & Anetoderma & 19 \\
6 & 45 & $>3 y$ & L shoulder & Atrophic dermatofibroma & CR1 \\
7 & 64 & NS & R mid & Atrophoderma, basal cell carcinoma, dermatofibroma, dermatofibrosarcoma & 30 \\
8 & 64 & $1 y$ & L upper & Atrophic dermatofibroma & CR2 \\
& & & back & & back \\
9 & 78 & NS & Back & Basal cell carcinoma & 9 C15 \\
$10-11^{\text {a }}$ & FN & FN & FN & FN & 7 \\
\hline
\end{tabular}

38 additional patients with an atrophic dermatofibroma have been described; however, neither the gender nor other clinical features were described [11-14, 22, 23, 27]

$C$ case, $D x A$ diagnosis age, $D u r$ duration of lesion prior to diagnosis, $F N$ footnote, $L$ left, $N S$ not stated, $R$ right, Ref reference, $y$ year

${ }^{a}$ A retrospective pathology-originating study identified 15 patients ( 2 men and 13 women) ranging from 19 to 79 years (median $=49.5$ years) with atrophic dermatofibroma who were observed in 2 years; the tumors had been present for an average duration of 5.8 years. The tumors were located on the shoulder (6), upper arm (3), lower limbs (3) and trunk (3). There was no identifiable cause and no previous steroid injections. The tumors presented as flat or retracted lesions (7) or nodules (4). The clinical differential diagnoses (23 submitted for the 15 patients) included basal cell carcinoma (10), scar (6), atrophy (1), Bowen's disease (1), dermatofibromasarcoma protuberans (1), lupus erythematosus (1), necrobiosis lipoidica (1), nevus lipomatosus (1) and nonspecific granuloma (1) [7]

the elastic fibers were increased in older lesions [32].

Zelger et al. evaluated 25 atrophic dermatofibromas. They performed Verhoeff-Van Gieson's staining on some of their specimens. However, they did not report the results [9].

Kiyohara et al. reported a 55-year-old woman with a $9 \times 7-\mathrm{mm}$ atrophic dermatofibroma of 6.5-years duration that presented as a relatively well demarcated, slightly elevated, dark red, oval plaque on her left upper back. The Verhoeff-Van Gieson elastic stain did not reveal any elastic fibers between the collagen fibers of the dermatofibroma compared with those observed in the adjacent normal skin. The researchers also evaluated four non-atrophic dermatofibromas; all of these also showed decreased-but not complete loss-of elastic fibers [17].

Ohnishi et al. described a 69-year-old woman whose atrophic dermatofibroma presented as a relatively well-demarcated, light brown, intracutaneous nodule. The left thigh lesion measured $23 \times 15 \mathrm{~mm}$; there was a $11 \times 8-\mathrm{mm}$ crateriform depression in the center of the lesion. The Verhoeff-Van Gieson stain showed greatly decreased or complete disappearance of the elastic fibers in the atrophic area of the lesional dermis; however, a dense presence of elastic fibers was observed around the mediumsized vessels in the lesional lower dermis [18].

Ohnishi et al. also evaluated eight non-atrophic dermatofibromas: three cellular benign 
Table 7 Location of atrophic dermatofibromas in 64 patients

\begin{tabular}{lcccccccc}
\hline Location & GNS \# & GNS \% & Men \# & Men \% & Women \# & Women \% & Total \# & Total \% \\
\hline Shoulder & 6 & 40.0 & 1 & 11.1 & 9 & 22.5 & 16 & 25.0 \\
Lower extremity & 3 & 20.0 & 0 & 0.0 & 10 & 25.0 & 15 & 23.4 \\
Below knee & 3 & 20.0 & 0 & 0.0 & 5 & 12.5 & 8 & 12.5 \\
Thigh & 0 & 0.0 & 2 & 22.2 & 5 & 12.5 & 7 & 10.9 \\
Back & 0 & 0.0 & 4 & 44.5 & 7 & 17.5 & 11 & 17.2 \\
Arm & 3 & 20.0 & 0 & 0.0 & 3 & 7.5 & 6 & 9.4 \\
Trunk & 3 & 20.0 & 1 & 11.1 & 1 & 2.5 & 5 & 7.8 \\
Breast & 0 & 0.0 & 0 & 0.0 & 4 & 10.0 & 4 & 6.2 \\
Axilla & 0 & 0.0 & 0 & 0.0 & 3 & 7.5 & 3 & 4.7 \\
Buttock & 0 & 0.0 & 1 & 11.1 & 2 & 5.0 & 3 & 4.7 \\
Neck & 0 & 0.0 & 0 & 0.0 & 1 & 2.5 & 1 & 1.6 \\
Total & 15 & 100.0 & 9 & 100.0 & 40 & 100.0 & 64 & 100.0 \\
\hline
\end{tabular}

GNS gender not specified [3]

fibrous histiocytomas, three histiocytic cellular variants and two intermediate types. In comparison to the presence of elastic fibers in the marginal areas, the fibers were completely absent in the three fibrous dermatofibromas and reduced by $20-30 \%$ in one of the five other dermatofibromas. Only one of the eight dermatofibromas showed elastic fibers around the vessels [18].

Mota et al. described a 57-year-old woman with a brown, mildly pruritic, well-defined, firm, $3 \times 2$-cm patch with an atrophic surface on her left flank of 10-years duration. The orcein elastic stain revealed an absence of elastic fibers in the middle of the lesion [26].

Morse et al. reported a 64-year-old man with a $12 \times 8$-mm indented, erythematous plaque with an ill-defined border on his right mid-back. The Verhoeff-Van Gieson elastic stain revealed a diffuse reduction of elastic tissue. However, there was an aggregation of elastic fibers at the periphery [30].

Our patients' atrophic dermatofibromas both had either absent or decreased elastic fibers in the tumor (Table 3). The 45-year-old man with the left shoulder atrophic dermatofibroma had no elastic fibers in his tumor; however, elastic fibers were observed in the dermis beneath the dermatofibroma (Fig. 3). The 64-year-old man with the left upper back atrophic dermatofibroma had an absence of elastic fibers in more than $90 \%$ of the tumor; elastic fibers were noted not only in the superficial portion of the tumor in the papillary dermis, but also-similar to our other patient-in the dermis beneath the dermatofibroma (Fig. 6).

\section{Immunohistochemistry}

Immunohistochemical staining may be used to differentiate dermatofibromas from dermatofibrosarcoma protuberans. Factor XIIIa and cluster of differentiation 34 (CD34) staining are often performed. Dermatofibromas demonstrate positive staining with factor XIIIa and an absence of staining with CD34; in contrast, dermatofibrosarcoma protuberans are not stained with factor XIIIa and show positive staining with CD34 [2-4, 33, 34].

Factor XIIIa and CD34 were evaluated in a study of 26 cases of atrophic dermatofibroma. Positive staining for factor XIIIa (ranging from 
Table 8 Clinical differential diagnosis of atrophic dermatofibroma

\begin{tabular}{|c|c|c|}
\hline Differential diagnosis $^{a}$ & Total \# & Total \% \\
\hline \multicolumn{3}{|l|}{ Neoplasm } \\
\hline \multicolumn{3}{|l|}{ Benign } \\
\hline Dermatofibroma & 14 & 17.7 \\
\hline Scar & 14 & 17.7 \\
\hline Nevus & 4 & 5.1 \\
\hline Neurofibroma & 1 & 1.3 \\
\hline Nevus lipomatosis & 1 & 1.3 \\
\hline Seborrheic keratosis, irritated & 1 & 1.3 \\
\hline Total & 35 & 44.4 \\
\hline \multicolumn{3}{|l|}{ Malignant } \\
\hline Basal cell carcinoma & 18 & 22.8 \\
\hline Dermatofibrosarcoma protuberans & 3 & 3.9 \\
\hline Squamous cell carcinoma in situ & 2 & 2.4 \\
\hline Melanoma & 1 & 1.3 \\
\hline Total & 24 & 30.4 \\
\hline \multicolumn{3}{|l|}{ Tumor cutis } \\
\hline Not otherwise specified & 3 & 3.9 \\
\hline Umbilicated & 2 & 2.4 \\
\hline Total & 5 & 6.3 \\
\hline Total & 64 & 81.1 \\
\hline \multicolumn{3}{|l|}{ Reactive dermatoses } \\
\hline Anetoderma & 5 & 6.3 \\
\hline Atrophoderma & 2 & 2.4 \\
\hline Atrophy & 1 & 1.3 \\
\hline Granuloma, nonspecific & 1 & 1.3 \\
\hline Panniculitis & 1 & 1.3 \\
\hline Total & 10 & 12.6 \\
\hline \multicolumn{3}{|l|}{ Systemic diseases } \\
\hline Morphea & 2 & 2.4 \\
\hline Lupus erythematosus & 1 & 1.3 \\
\hline Necrobiosis lipoidica & 1 & 1.3 \\
\hline Sarcoidosis & 1 & 1.3 \\
\hline
\end{tabular}

Table 8 continued

\begin{tabular}{lcc}
\hline Differential diagnosis $^{\mathbf{a}}$ & Total \# $^{\text {Total \% }}$ \\
\hline Total & 5 & 6.3 \\
TOTAL & 79 & 100.0 \\
\hline
\end{tabular}

${ }^{a}$ The pathology requisition slip submitted by the clinician listed one or more possible diagnoses for 52 of the patients with an atrophic dermatofibroma; a clinical diagnosis was not provided for 12 of the patients (11 women and 1 man) in Tables 5 and 6

10 to $50 \%)$ was noted in 20 (73\%) of the cases; there was absence of staining for 6 of the women's tumors. However, 2 of the factor XIIIapositive tumors also stained with CD34: 25\% positivity of a lesion on the thigh of a 32-yearold man and $75 \%$ positivity of a lesion on the axilla of a 66-year-old woman [9].

Factor XIIIa was also positive in other women [10, 17, 21, 26, 29] and men [19, 24] whose atrophic dermatofibromas were evaluated. Yet, one man's tumor-a 27-year-old with an atrophic dermatofibroma of 2-years duration on his back-was factor XIIIa-negative [20].

Focal CD34-positive staining was also observed in atrophic dermatofibromas of two additional women [10, 29] and one man [20]. One woman was 45 -years old with a right axilla tumor, and the other woman was 64-year-old with a left thigh tumor; the latter woman's atrophic dermatofibroma had been present for more than 40 years. The man was the 27 -yearold whose back tumor of 2-years duration was also factor XIIIa-negative [20].

The etiology of the unexpected absence of factor XIIIa expression and the aberrant CD34 staining remains to be determined. In old dermatofibromas, factor XIIIa immunoreactivity may be lost as a result of increasing sclerosis and fibroblast-like differentiation of dendrocytes [10]. Positive staining for CD34 in atrophic dermatofibromas may be secondary to a background/demarcation phenomenon; this results when the background is rich in small, flattened 
vessels and nonspecific staining with CD34 occurs $[9,10,19]$.

\section{Electron Microscopy}

The atrophic dermatofibroma on the left upper back of a 55-year-old woman was examined. The ultrastructural examination coincided with the light microscopy observations: only a few elastic fibers were found in the extracellular spaces of the dermatofibroma. However, intracellular elastic fibers-surrounded by double membranes-were noted within the tumor cells of the dermatofibroma [17].

\section{Differential Diagnosis}

The clinical differential diagnosis of atrophic dermatofibromas includes benign and malignant neoplasms, reactive dermatoses and systemic diseases (Table 8) [7-10, 15, 16, 18-21, 24-26, 28-30, current report]. Seventy-nine diagnoses were suggested by the clinicians who biopsied 52 of the patients; there were 12 patients (11 women and 1 man) for whom a clinical diagnosis was not stated. For those individuals in whom the information was available (37 patients), the number of diagnoses submitted ranged from one (27 patients) to six (one patient); the median number of submitted diagnoses was one. Two diagnoses were considered in seven patients, and five diagnoses were entertained in one patient.

Basal cell carcinoma was the most common diagnosis (18 patients); this represented $22.8 \%$ ( 23 of 79 submitted diagnoses) of the diagnoses suggested on the pathology requisition. The next most frequent diagnoses-each listed 14 times-were dermatofibroma and scar. Anetoderma and tumor cutis (each in five patients), nevus (in four patients), dermatofibrosarcoma protuberans (in three patients), and squamous cell carcinoma in situ, atrophoderma and morphea (each in two patients) were the other diagnoses suggested more than once.

The pathologic differential diagnosis of atrophic dermatofibroma included dermatofibrosarcoma protuberans in some of the patients. However, the use of immunohistochemical staining with factor XIIIa and CD34 aided in establishing the correct diagnosis. The atrophic dermatofibromas were usually factor XIIIa-positive and CD34-negative.

\section{Pathogenesis}

The etiology of dermatofibromas remains to be definitively established. Some investigators favor that dermatofibromas are a reactive process. About a fifth of the patients with cellular benign dermatofibromas have a history of trauma (such as an insect bite) or injection at the site of the lesion. However, most dermatofibromas develop spontaneously [4].

Other researchers suggest a neoplastic process for the development of dermatofibromas. Clonal markers-implying a monoclonal pattern-in the cells of dermatofibromas have been identified [4].

A heterogenous pathogenesis of dermatofibromas has also been entertained. This would include both a reactive process and a neoplastic process within the individual lesion. A fibroblastic proliferation of the fibrous portion would compose the reactive component, and a histiocytic proliferation would account for the neoplastic component [4].

The etiology of atrophic dermatofibromas may be similar to that of non-atrophic dermatofibromas. Both variants of dermatofibroma are more common in women. However, a history of trauma or injection is always absent in patients with atrophic dermatofibromas.

There is also a difference in lesion location. Cellular benign dermatofibromas most commonly occur on the legs. In contrast, atrophic dermatofibromas most frequently occur on the shoulder $(25 \%)$, followed by the lower extremities (23\%) and back (17\%).

\section{Treatment}

An atrophic dermatofibroma is a benign vascular lesion. For some of the patients, the diagnosis was based on clinical features, and no intervention was performed [27]. In other individuals, including the men described in this paper, the residual lesion was observed after the biopsy $[7,24,30]$. However, the tumors were 
excised-either at the time of biopsy or subsequently-for many of the patients $[7,8,17,19-21,26,29]$. Several of the investigators did not describe the management of the tumor $[9,15,16,27,28]$.

\section{CONCLUSIONS}

An atrophic dermatofibroma is an uncommon benign variant of a dermatofibroma that has been reported in 102 patients. It is five times more common in women (53) than men (11); the gender was not provided for 38 individuals. It usually presents as an asymptomatic solitary patch on the shoulder of women aged 48 years and older; the central area is typically depressed. Other common sites include the lower extremity or back. White scar-like patches can be seen on dermoscopic examination; a patchy pigment network may also be present. The pathology of an atrophic dermatofibroma can show acanthosis, basal layer hyperpigmentation, and induction of basal cell carcinoma-like features, hair follicle formation or sebaceous hyperplasia in the epidermis; a proliferation of spindle-shaped fibroblasts is present in the dermis. Depression of the central surface and thinning of the dermis-in many cases, with at least 50 percent of dermal atrophy-can also be noted. Elastic fibers within the dermal tumor are either decreased or absent. The immunoperoxidase profile of an atrophic dermatofibroma is factor XIIIa-positive and CD34negative. The pathogenesis of an atrophic dermatofibroma remains to be established. Although the diagnosis of an atrophic dermatofibroma may be suspected based on the clinical features of the lesion and the dermatoscopic findings, a biopsy of the lesion will confirm the diagnosis. If an excisional biopsy was performed, the tumor was removed at the time of diagnosis. Otherwise, the patient may elect to observe the residual lesion if the biopsy only includes part of the tumor; in this setting, periodic evaluation of the lesion site is a reasonable approach to the management of the residual tumor.

\section{ACKNOWLEDGEMENTS}

We thank the participants in the study.

Funding. No funding or sponsorship was received for this study or publication of this article.

Authorship. All named authors meet the International Committee of Medical Journal Editors (ICMJE) criteria for authorship for this article, take responsibility for the integrity of the work as a whole, and have given their approval for this version to be published. The authors are fully responsible for all content and received no financial support or any other form of compensation related to the development of this manuscript.

Disclosures. Philip R. Cohen, Christof P. Erickson and Antoanella Calame have nothing to disclose with regards to the publication of this article. Philip R. Cohen is a member of the journal's Editorial Board

Compliance with Ethics Guidelines. Informed consent was obtained from the participants for their inclusion in the study. The patients also signed a consent form providing permission to include clinical photographs in this article.

Data Availability. All data generated or analyzed during this study are included in this published article.

Open Access. This article is distributed under the terms of the Creative Commons Attribution-NonCommercial 4.0 International License (http://creativecommons.org/licenses/ by-nc/4.0/), which permits any noncommercial use, distribution, and reproduction in any medium, provided you give appropriate credit to the original author(s) and the source, provide a link to the Creative Commons license, and indicate if changes were made. 


\section{REFERENCES}

1. Canelas MM, Cardoso JC, Andrade PF, Reis JP, Tellechea O. Fibrous histiocytomas: histopathologic review of 95 cases. An Bras Dermatol. 2010;85:211-5.

2. Luzar B, Calonje E. Cutaneous fibrohistiocytic tumours-an update. Histopathology. 2010;56:148-65.

3. Han TY, Chang HS, Lee JH, Lee WM, Son SJ. A clinical and histopathological study of 122 cases of dermatofibroma (benign fibrous histiocytoma). Ann Dermatol. 2011;23:185-92.

4. Myers DJ, Fillman EP. Dermatofibroma. StatPearls. Treasure Island: StatPearls Publishing; 2018. p. 27.

5. Beatrous SV, Riahi RR, Grisoli SB, Cohen PR. Associated conditions in patients with multiple dermatofibromas: case reports and literature review. Dermatol Online J. 2017;23(9):13030.

6. Zelger BG, Sidoroff A, Zelger B. Combined dermatofibroma: co-existence of two or more variant patterns in a single lesion. Histopathology. 2000;36:529-39.

7. Beer M, Eckert F, Schmoeckel C. The atrophic dermatofibroma. J Am Acad Dermatol. 1991;25:1081-2.

8. Requena L, Reichel M. The atrophic dermatofibroma: a delled dermatofibroma. J Dermatol. 1995;22:334-9.

9. Zelger BW, Ofner D, Zelger BG. Atrophic variants of dermatofibroma and dermatofibrosarcoma protuberans. Histopathology. 1995;26:519-27.

10. Hendi A, Jukic DM, Kress DW, Brodland DG. Atrophic dermatofibroma: a case report and review of the literature. Dermatol Surg. 2002;28:1085-7.

11. Kelati A, Aqil N, Baybay H, Gallouj S, Mernissi FZ. Beyond classic dermoscopic patterns of dermatofibromas: a prospective research study. J Med Case Rep. 2017;11:266.

12. Temime P, Odoze L. Histiocyto-fibrome invagine ou retractile. Bull de la Soc Franc Dermat et de Syph. 1960;67:280-1.

13. Lefranc M, Simard C. Histiocytoma retractile. Bull de la Soc Franc Dermat et de Syph. 1964;71:548-9.

14. Arguelles-Casals D, Rodriguez D. Histiofibroma: considerations about 75 cases. Dermatologica Revista Mexicana. 1968;12:333-9.
15. Gabrielli M, Cazenave JM, Cabrera HN, Gaviglio AM, Costa JA. Histiocytoma. Spontaneous regression, leaving skin atrophy. Med Cutan Iber Lat Am. 1975;3:119-23.

16. Page EH, Assaad DM. Atrophic dermatofibroma and dermatofibrosarcoma protuberans. J Am Acad Dermatol. 1987;17:947-50.

17. Kiyohara T, Kumakiri M, Kobayashi H, Ohkawara A, Lao LM. Atrophic dermatofibroma. Elastophagocytosis by the tumor cells. J Cutan Pathol. 2000;27:312-5.

18. Ohnishi T, Sasaki M, Nakai K, Watanabe S. Atrophic dermatofibroma. J Eur Acad Dermatol Venereol. 2004;18:580-3.

19. Curco N, Pagerols X, Garcia M, Tarroch X, Vives P. Atrophic dermatofibroma accompanied by aneurysmatic characteristics. J Eur Acad Dermatol Venereol. 2006;20:331-4.

20. Shin JW, Park HS, Kim BK, Kim YA, Kim MG, Won $\mathrm{CH}$, Cho S. Aneurysmal benign fibrous histiocytoma with atrophic features. Ann Dermatol. 2009;21:42-5.

21. Villareal-Martinez A, Chavez-Alvarez S, Herz-Ruelas M, Miranda-Maldonado I, Vazquez-Martinez O. An atrophic plaque with arborizing vessels. Case Rep Dermatol. 2016;8:239-42.

22. Kilinc Karaarslan I, Gencoglan G, Akalin T, Ozdemir F. Different dermoscopic faces of dermatofibromas. J Am Acad Dermatol. 2007;57:401-6.

23. Ferrari A, Argenziano G, Buccini P, Cota C, Sperduti I, De Simone P, Eibenschutz L, Silipo V, Zalaudek I, Catricala C. Typical and atypical dermatoscopic presentations of dermatofibroma. J Eur Acad Dermatol Venereol. 2013;27:1375-80.

24. Reynolds H, Perry A, Satter EK. Multiple clustered and focally atrophic dermatofibromas (DF). Dermatol Online J. 2014;20(5):22612.

25. Kim EH, Kang HY, Lee ES, Kim YC. Two cases of dermatofibroma with atrophic features. Korean J Dermatol. 2007; 45:305-8.

26. Mota AN, Tortelly VD, Obadia DL, Silva RS. Atrophic dermatofibroma. An Bras Dermatol. 2013;88:793-5.

27. Alves JV, Matos DM, Barreiros HF, Bartolo EA. Variants of dermatofibroma-a histopathological study. An Bras Dermatol. 2014;89:472-7.

28. Bandyopadhyay MR, Besra M, Dutta S, Sarkar S. Dermatofibroma: atypical presentations. Indian J Dermatol. 2016;61(1):121. 
29. Morse MO, Gru AA, Kaffenberger J. A 64-year-old woman with an atrophic plaque on the thighQuestion. Answer: atrophic dermatofibroma. Am J Dermatopathol. 2017;39:45-6.

30. Morse DC, Tschen JA, Silapunt S. Atrophic dermatofibroma in an elderly male-a rarely described variant of a common lesion. Dermatol Online J. 2018;24(6):13030.

31. Arpaia N, Cassano N, Vena GA. Dermoscopic patterns of dermatofibroma. Dermatol Surg. 2005;31:1336-9.

32. Ahn SK, Lee NH, Kang YC, Choi EH, Hwang SM, Lee $\mathrm{SH}$. Histopathologic and immunohistochemical findings of dermatofibromas according to the clinical features and duration. Korean J Dermatol. 2000;38:5000-505.

33. Cohen PR, Rapini RP, Farhood AI. Expression of the human hematopoietic progenitor cell antigen CD34 in vascular and spindle cell tumors. J Cutan Pathol. 1993;21:15-20.

34. Cohen PR, Rapini RP, Farhood AI. Dermatopathologic advances in clinical research. The expression of antibody to CD34 in mucocutaneous lesions. Dermatol Clin. 1997;15:159-76. 